International Journal of Public Health Excellence (IJPHE)

Vol. 1, No. 1, January 2022, pp. 17 20

Journal homepage: https://ejournal.ipinternasional.com/index.php/ijphe/

ISSN: 2809-9826, DOI: https://doi.org/10.55299/ijphe.v1i1.6

\title{
Factors Affecting Sectio Caesarea Delivery at the Padangsidimpuan City Regional General Hospital
}

\author{
Nikmatul Khoiriyah Pulungan ${ }^{1}$, Meilani Harahap ${ }^{2}$, Ennysah Hasibuan ${ }^{3}$ \\ ${ }^{1,2,3} \mathrm{D} 3$ Midwifery Study Program, Padangsidimpuan Matorkis Midwifery Academy, Indonesia
}

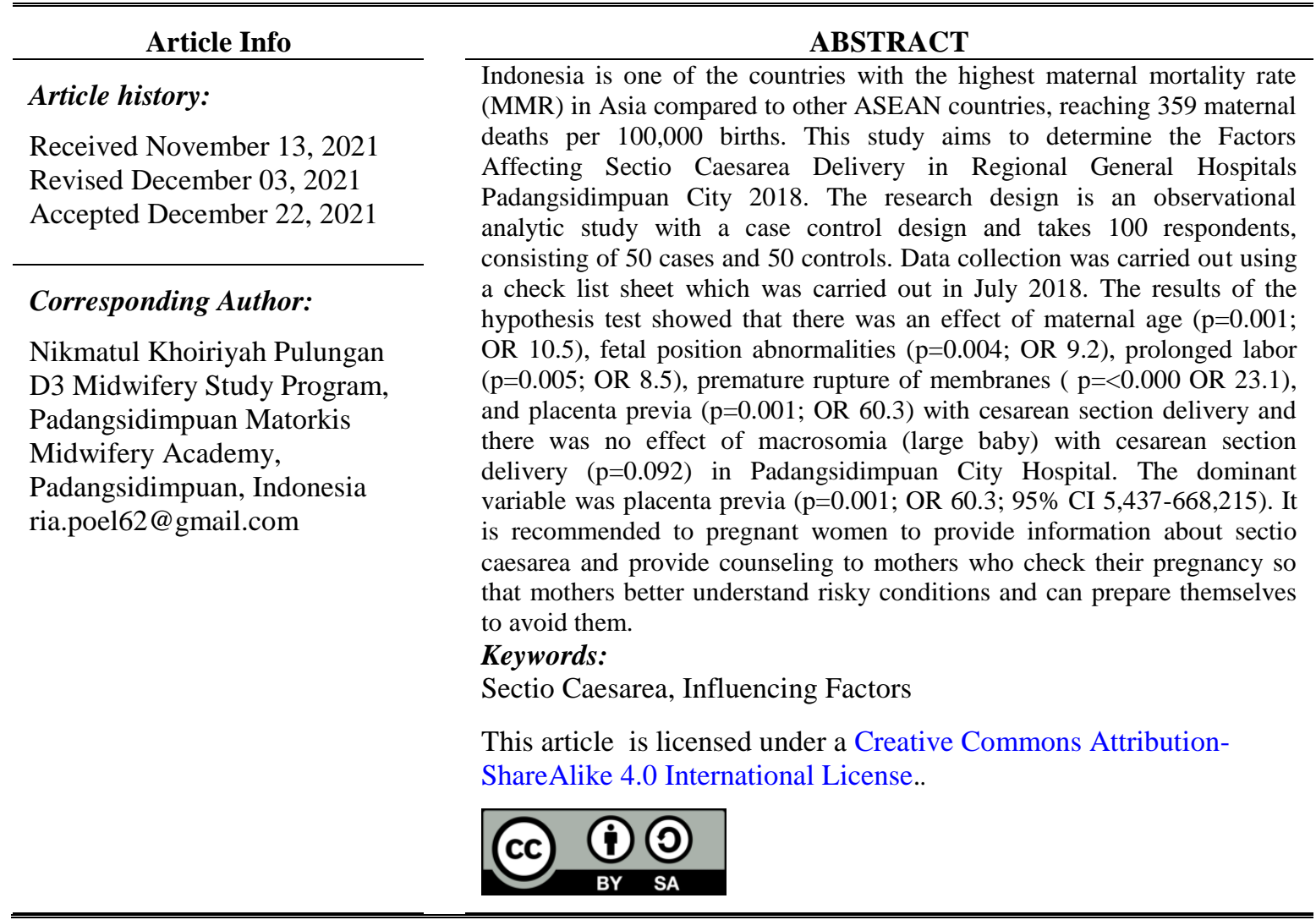

\section{INTRODUCTION}

Childbirth is a critical period for pregnant women. The problem of complications or the presence of complicating factors is a risk factor for maternal death so that medical action is needed as an effort to save the mother and child. [3]

Sectio Caesarea is an artificial birth process that is performed surgically by making incisions in the abdominal wall and uterine wall of the mother, provided that the uterus is intact, and the fetus weighs above 500 grams. If the weight of the fetus is below 500 grams, there is no need for a cesarean delivery.[4]

The standard of caesarean section in a country according to WHO is 5-15\%. In Indonesia alone, the percentage of sectiocaesarea is around 5\%. In government hospitals the average is 11 percent, while in private hospitals the average is 30 percent, this number continues to grow. Various surveys found that the percentage of secretariat deliveries in hospitals in big cities such as Jakarta and Bali was far above that figure. In general, the number of cesarean deliveries in government hospitals is around $30-35 \%$ of the total births while in private hospitals the number is very high, which is around $30-80 \%$ of the total births.[5] [6]

According to the Indonesian Demographic and Health Survey (IDHS), 12\% of births were performed by caesarean section. Women who gave birth by caesarean section were mostly those aged 35-49 years (15\%), those who gave birth in the first order (14\%), women who lived in urban areas (17\%), women who graduated from high school and college colleges (19\% and $25 \%$, respectively), and women in the highest wealth quintile (23\%). The caesarean section rate is higher in the 2012 IDHS compared to the 2007 IDHS.[7]

MMR and IMR in Indonesia are still quite high. This is caused by various factors. One of them is the presence of complications in childbirth, including caesarean section. According to Bensons and Pernolls, the maternal mortality rate for cesarean delivery is 40-80 per 100,000 live births. Caesarean delivery has a 25 times greater risk of death than vaginal delivery. [4] 
Based on data found at the Padangsidimpuan City Hospital in 2016 the number of cesarean section births was 341 births out of 509 births, while in 2017 the number of caesarean sections increased by 560 births and 3 mothers died of 808 births. The proportion of causes of caesarean section included narrow or cephalopelvic disproportion (CPD) 134 cases, 117 cases of prolonged labor, 67 cases of premature rupture of membranes, 58 cases of cesarean section, 53 cases of breeches, and 42 cases of placenta previa. From the data obtained above, it shows that there is an increase in caesarean deliveries from year to year and there are still many unknown factors with the provision of sectio caesarea so that researchers are interested in conducting research on "Factors Affecting Sectio Caesarea Labor at Padangsidimpuan City General Hospital in 2018. [8]

\section{METHOD}

The type of research used is an observational analytic study with a case control design by selecting mothers who underwent caesarean section as cases and mothers who gave birth vaginally as controls. The reason for using this design is because a case-control study is an observational study that assesses the association of disease exposure by comparing case groups and control groups based on their exposure status. The population in this study were all mothers who gave birth at the Padangsidimpuan City Hospital for the period January 2017 to December 31, 2017 totaling 808 people.[9]

\section{RESULTS AND DISCUSSION}

\subsection{Effect of Maternal Age with Sectio Caesarea Delivery at Padangsidimpuan City Regional General Hospital}

Based on the results of the study, it showed that there was a significant effect of maternal age with cesarean delivery at the Padangsidimpuan City Hospital in 2018 ( $p=0.000$; OR 5,464; 95\% Cl 2,320 - 12,872).

Age is one of the factors that can be a complication in childbirth. The ideal reproductive age for a mother is between 20-35 years. Age under 20 years and over 35 years will increase the risk of pregnancy and childbirth. From a psychological point of view, in women less than 20 years of age their mental development is still not ripe for motherhood. From a physical point of view, at a young age a woman's reproductive organs are not perfect so that it can lead to obstetric complications. [4]

Meanwhile, those over the age of 35 have a three times greater risk of having a cesarean section than those under the age of 35 . More than 35 years are included in the high-risk age group in pregnancy and childbirth. At this age, various problems often accompany pregnancy, such as placenta previa totalis, severe preeclampsia, fatigue in straining, and so on. In Iran, his study found that there was a relationship between maternal age over 35 years and delivery by cesarean section, and pregnancy complications, such as preeclampsia and malpresentation. [4]

\subsection{The Effect of Fetal Position Abnormalities with Sectio Caesarea Delivery at the Padangsidimpuan City Regional General Hospital}

Based on the results of the study, it showed that there was a significant effect on the location of fetal abnormalities with cesarean delivery at the Padangsidimpuan City Hospital in 2018 ( $\mathrm{p}=0.016 ; \mathrm{OR} 2.705 ; 95 \% \mathrm{Cl}$ 1.197-6.113).

Abnormal position of the fetus is one of the complications of the baby that can cause normal birth can not be done. Location of the fetus in the uterus, breech location and latitude. The condition of the fetus is breech if the location of the fetus in the uterus extends with the head at the top of the uterus, while the buttocks are under the uterine cavity, while what is meant by "position" is the lowest. baby's condition. The risk of a baby being born breech in natural delivery is estimated to be 4 times greater than that of a baby born in a normal head position. Therefore, usually the last step to anticipate the worst as a result of delayed labor due to a breech fetus is surgery. [1]

\subsection{The Effect of Old Partus with Sectio Caesarea Delivery at the Padangsidimpuan City Regional General Hospital}

Based on the results of the study, it showed that there was a significant effect of prolonged labor with cesarean delivery at the Padangsidimpuan City Hospital in 2018 ( $p=0.000$; OR 5,785; 95\% Cl 2,400-13,984).

The undeveloped part was an adequate delivery that showed no progress in cervical dilatation, head descent and vascular twisting during the last 2 hours. Labor is said to be long if it is more than 24 hours for primigravida and more than 18 hours for multigravida.[2]

Childbirth helps in prolonged labor, i.e. when labor arrives, but the contractions that occur are not as expected, so it is necessary to do induction, if the contractions are still not good then delivery is assisted with forceps (vacuum) but if this method does not work it will be done immediately by sectio caesarea.[1]

\subsection{Effect of Premature Rupture of Membranes with Sectio Caesarea Delivery at Padangsidimpuan City Regional General Hospital}

Based on the results of the study showed that there was a significant effect of premature rupture of membranes with cesarean delivery at Padangsidimpuan City Hospital in 2018 ( $\mathrm{p}=0.000$; OR 7,319; Cl 3,025-17,705). Premature rupture of membranes is a condition in which the membranes rupture before labor has started or if labor has started but the dilation is less than $3 \mathrm{~cm} .[2]$

Premature rupture of the amniotic sac can cause the baby to be delivered immediately. This condition allows amniotic fluid to seep out so that it remains low or depleted. Amniotic fluid is the fluid that surrounds the fetus in the 
uterus. Around $60-70 \%$ of babies whose pregnancies have premature rupture of membranes will be born alone for a maximum of $2 \times 24$ hours. If the baby is not born after that time, the doctor will take action, namely a cesarean section.[1]

\subsection{The Effect of Placenta Previa with Sectio Caesarea Delivery at the Padangsidimpuan City Regional General Hospital}

Based on the results of the study showed that there was a significant effect of placenta previa with cesarean delivery at Padangsidimpuan City Hospital in 2018 ( $\mathrm{p}=0.014$; OR 6,000; 95\% Cl 1.242 - 28.987)

Placenta previa is divided into three, namely marginal placenta praevia, partial placenta previa, and total placenta previa. Pregnancy with marginal placenta previa is, the edge of the placenta is right at the edge of the opening. Placenta previa partialis i.e., part of the surface is covered by tissue, but delivery can still be done vaginally, as long as it is performed by a trained person. Pregnancy with total placenta previa, i.e. the end of the placenta is right at the edge of the opening. In this condition, delivery cannot be carried out with vaginal discharge, but by caesarean section because the placenta covers the mother's birth canal.[4]

Abnormal fetal position causes pathological birth, if the lateral placenta previa ruptures or ruptures the membranes, funicular prolapse may occur, primary unertia and bleeding are often found.[2]

\subsection{The Effect of Macrosomia with Sectio Caesarea Delivery at the Padangsidimpuan City Regional General Hospital}

Based on the results of the study, it showed that there was no effect of macrosomia with cesarean delivery at Padangsidimpuan Hospital in 2018 ( $\mathrm{p}=0.092$ ).

Babies born weighing 4,000 grams or more (giant babies), making it difficult for the baby to get out of the birth canal. Generally, excessive fetal growth (macrosomia) because the mother has diabetes (diabetes mellitus). Assistance for infants with this condition can be provided by vaginal delivery if the mother is multiparous and is known to have a normal pelvic area.[1]

This result is not in line with Wulandari et al who found that the factors that contributed significantly to cesarean delivery included macrosomia. The condition of a child's birth weight that is above the average normal birth weight (> 4000 grams) is the cause of the mismatch with the size of the mother's pelvis so that a normal birth cannot be performed. The effect of the incidence of children with macrosomia and caesarean section was found to be significant $(\mathrm{p}=0.0001)$ with $\mathrm{OR}=155,167 ; \mathrm{CI}=19,317-1245,410 .[10]$

\section{CONCLUSION}

Based on the results of the study, it was found that the factors that influenced the delivery of cesarean section at the Padangsidimpuan City Regional General Hospital in 2018.

There is an influence of maternal age with sectio caesarea delivery at the Padangsidimpuan City Regional General Hospital. There is an influence on fetal position abnormalities with caesarean section delivery at the Padangsidimpuan City Regional General Hospital. There is an effect of prolonged labor with sectio caesarea delivery at the Padangsidimpuan City Regional General Hospital. There is an effect of premature rupture of membranes with caesarean section delivery at the Padangsidimpuan City Regional General Hospital. There is an effect of placenta previa with cesarean section delivery at the Padangsidimpuan City General Hospital. There is no effect of macrosomia (large baby) with caesarean section delivery at the Padangsidimpuan City Regional General Hospital. The most dominant variable at risk of influencing the delivery of cesarean section at the Padangsidimpuan City General Hospital was placenta previa with an OR of 60.3 .

\section{ACKNOWLEDGEMENTS}

Author thanks Meilani Harahap, Ennysah Hasibuan In most cases, sponsor and financial support.

\section{REFERENCES}

[1] Kasdu, D, “Caesarean section”. Jakarta: Puspa Swara, 2016.

[2] Maryunani, A, "Practical Book of Pathological Pregnancy and Childbirth", Jakarta: Media Trans Info, 2016.

[3] Basic Health Research, "Basic Health Research and Development Agency", Ministry of Health Republic of Indonesia. 2013.

[4] Solehati, T, Kosasih, C, E, "Concepts and Applications of Relationships in Maternity Nursing", Bandung: Refika Aditama, 2017.

[5] Aini, H, "Smart Book Living 9 Months of Pregnancy", Tora Book. Yogyakarta, 2009.

[6] Rasyid, "The Effect of Hypnotherapy on the Anxiety Level of Mothers Who Will Have a Cesarean Section", UNSemar. Semarang, 2009

[7] Indonesia Demographic and Health Survey, "Measuring the achievement of the targets of the national health program, especially those related to maternal and child health development programs", Central Bureau of Statistics, Republic of Indonesia, 2012

[8] Padangsidimpuan City Hospital, "Number of deliveries by cesarean section", Padangsidimpuan, 2016.

[9] Notoatmodjo, "Health Research Methodology", Jakarta: PT Rineka Cipta, 2017.

[10] Wulandari. Dkk, "Postpartum Midwifery Care", Jogjakarta : Mitra Cendekia. 2009.

[11] Andayasari, L., Muljati, S., Sihombing, M., Arlinda, D., Opitasari, C., Mogsa, D. F., \& Widianto, W, "Proportion of cesarean sections and factors associated with cesarean sections in Jakarta", Health Research Bulletin, 43(2). https://doi.org/10.22435/bpk.v43i2.4144.105-116

[12] Arman, S. R, "Factors Associated with the Selection of Sectio Caesarea Delivery Methods at the Great Hospital Jakarta for the period November 2016-October 2017”, Journal of Chemical Information and Modeling, 53, No. 9, 2017 
[13] Pilliod, R. A., \& Caughey, A. B, "Fetal Malpresentation and Malposition: Diagnosis and Management. In Obstetrics and Gynecology Clinics of North America", Vol. 44, Issue 4. https://doi.org/10.1016/j.ogc.2017.08.003

[14] Prawirohardjo, S, "Midwifery Science Sarwono Prawirohardjo. 4th Edition", Jakarta: Sarwono Prawirohardjo Foundation Bina Pustaka, 2016.

[15] Rivai, F., Koentjoro, T., \& Utarini, A, "Determinants of Post-C-section Wound Infection", Public Health: National Public Health Journal, 8(5). https://doi.org/10.21109/kesmas.v8i5.390

[16] Manuaba, I.G.B, "Kapita Selecta Routine Management of Obstetrics, Gynecology and Family Planning”, Jakarta : EGC, 2001.

[17] Mitayani, "Maternity Nursing Care", Jakarta: Penerbit Salemba Medika, 2009

[18] Moleong, L J. "Qualitative Research Methodology", Bandung : Jemmars, 2004.

[19] Prawirohardjo, S, " Midwifery", Jakarta : Bina Pustaka, 2008.

[20] Sinsin, Iis, "Maternal and Child Health Series Pregnancy and Childbirth", Jakarta : PT Alex Media Komputindo, 2008.

[21] Winkjosastro, H, "Midwifery", Jakarta : Bina Pustaka Prawirohardjo, 2006

[22] Cunningham, F, et al, "Obstetrics William Edition 21", Jakarta : EGC, 2006

[23] Farrer, Helen, "Maternity Care Issue 2", Jakarta :EGC, 2001.

[24] Himatusujanah, "Mother's Behavior of Sectio Caesarea towards Sectio Caesarea Wound Treatment at Mitra Sejati General Hospital, Medan", Undergraduate, University of Northern Sumatra, Medan, Indonesia 2008

[25] Mitayani, "Maternity Nursing Care", Jakarta: Penerbit Salemba Medika, 2009 